\title{
Grafting of Copper(I)-NHC Species on MCM-41: Homogeneous versus Heterogeneous Catalysis
}

\author{
Karin Garcés, Francisco J. Fernández-Alvarez, ${ }^{*}$ Pilar García-Orduña, Fernando J. Lahoz, Jesús J. \\ Pérez-Torrente and Luis A. Oro*
}

Dedication ((optional))

\begin{abstract}
The copper $(\mathrm{I})$ complexes $[\mathrm{Cu}(\mathrm{X})\{2,6-$ diisopropylphenyl-NHC- $\left.\left.\left(\mathrm{CH}_{2}\right)_{3} \mathrm{Si}(\mathrm{OiPr})_{3}\right\}\right] \quad(\mathrm{X}=\mathrm{Cl}(\mathbf{2 a})$; I (2b)) have been synthetized and characterized. Furthermore, the structure of $\mathbf{2} \mathbf{b}$ has been confirmed by X-ray diffraction studies. Complex $\mathbf{2 a}$ has been successfully anchored in MCM-41 to afford 2-MCM-41. The activity of both the homogeneous, 2a, and heterogeneous, 2-MCM-41, catalysts in acetophenone hydrosilylation with $\mathrm{HSiEt}_{3}$ and [3+2] cycloaddition of benzyl azide and phenylacetylene has been investigated. The heterogeneous catalyst exhibits catalytic activity for the cycloaddition reaction though, unexpectedly, showed no catalytic activity for hydrosilylation.
\end{abstract}

\section{Introduction}

Hydrosilylation catalysts are frequently based on expensive and scarce metals such as Pt or $\mathrm{Rh}^{\left[{ }^{[1]}\right.}$ Therefore, the development of new catalysts based on cheap and abundant metals is desired. In this context, it is noteworthy that copper- $\mathrm{NHC}(\mathrm{NHC}=\mathrm{N}$ heterocyclic carbene) complexes of the type $[\mathrm{Cu}(\mathrm{Cl})(\mathrm{NHC})]$ have proven to be efficient catalyst precursors for the catalytic hydrosilylation of carbonyl compounds. ${ }^{[2]}$ Theoretical and experimental studies support that $[\mathrm{Cu}(\mathrm{H})(\mathrm{NHC})]$ intermediates, which have been characterized in solution, act as active species in such catalytic processes. ${ }^{[3,4]}$

The use of $[\mathrm{Cu}(\mathrm{Cl})(\mathrm{NHC})]$ complexes as catalyst precursors in reduction reactions involving hydrosilanes requires a previous activation step, which frequently consists in the reaction of the $\mathrm{Cu}-\mathrm{Cl}$ bond with an alkaline alkoxide, for instance $\mathrm{KOtBu}$, to give the corresponding $[\mathrm{Cu}(\mathrm{alkoxo})(\mathrm{NHC})]$ species, which by reaction with hydrosilanes produces the active catalyst, $[\mathrm{Cu}(\mathrm{H})(\mathrm{NHC})]$, and the corresponding silylether ${ }^{[2-4]}$ It has been reported that an enhancement of the base concentration, usually $t \mathrm{BuO}^{-}$, exerts a positive effect in the activity of $[\mathrm{Cu}(\mathrm{Cl})(\mathrm{NHC})]$ species, which

[a] Dr. K. Garcés, Dr. F. J. Fernández-Alvarez, Dr. P. García-Orduña, Prof. F. J. Lahoz, Prof. J. J. Pérez-Torrente and Prof. L. A. Oro. Departamento de Química Inorgánica - Instituto de Síntesis Química y Catálisis Homogénea (ISQCH) Universidad de Zaragoza - Consejo Superior de Investigaciones Científicas (CSIC).

PI. San Francisco S/N, 50009 Zaragoza - Spain

E-mail: paco@unizar.es, oro@unizar.es suggests a non-innocent role of the Lewis base (LB). Indeed, pentavalent hydrosilicate intermediates, $\left[\mathrm{HSiR}_{3}(\mathrm{LB})\right]^{-}$, in-situ generated by coordination of the LB to the silicon atom, have been proposed as the silicon containing active species in $\mathrm{Cu}$ $\mathrm{NHC}$ catalyzed ketones hydrosilylation processes. ${ }^{[5]}$

Herein, we describe the synthesis and characterization of the new copper(I) complexes [Cu(X)\{2,6-diisopropylphenyl-NHC$\left.\left.\left(\mathrm{CH}_{2}\right)_{3} \mathrm{Si}(\mathrm{OiPr})_{3}\right\}\right] \quad(\mathrm{X}=\mathrm{Cl}(\mathbf{2 a}) ; \quad \mathrm{I}(\mathbf{2 b}))$, which are efficient precatalysts for the hydrosilylation of ketones and the 1,3-dipolar cycloaddition of organic azides to alkynes. In sharp contrast, the heterogeneous catalysts resulting from the immobilization of complex $\mathbf{2 a}$ on MCM-41 showed catalytic activity for the cycloaddition reaction although were inactive for acetophenone hydrosilylation.

\section{Results and Discussion}

Preparation of $\mathrm{Cu}-\mathrm{NHC}$ with a $\mathrm{Si}(\mathrm{OiPr})_{3}$-functionalized $\mathrm{NHC}$ ligand. $\mathrm{Ag}(\mathrm{I})-\mathrm{NHC}$ species are commonly used as transmetallation reagents for the preparation of transition metalNHC complexes. ${ }^{[6]}$ The reaction of the imidazolium salt 1-(3triisopropoxysilylpropyl)-3-(2,6-diisopropylphenyl)-imidazolium iodide (1) with $\mathrm{Ag}_{2} \mathrm{O}$ provides solutions containing the corresponding $\mathrm{Ag}(\mathrm{I})-\mathrm{NHC}$ species, ${ }^{[7]}$ which react with $\mathrm{CuX}(\mathrm{X}=$ $\mathrm{Cl}, \quad \mathrm{I})$ to afford the copper(I) complexes $[\mathrm{Cu}(\mathrm{X})\{2,6$ diisopropylphenyl-NHC- $\left.\left.\left(\mathrm{CH}_{2}\right)_{3} \mathrm{Si}(\mathrm{OiPr})_{3}\right\}\right](\mathrm{X}=\mathrm{Cl}, \mathbf{2 a} ; \mathbf{I}, \mathbf{2 b})$, which were isolated as off-white solids in $75 \%$ and $50 \%$ yield, respectively (Scheme 1 ).

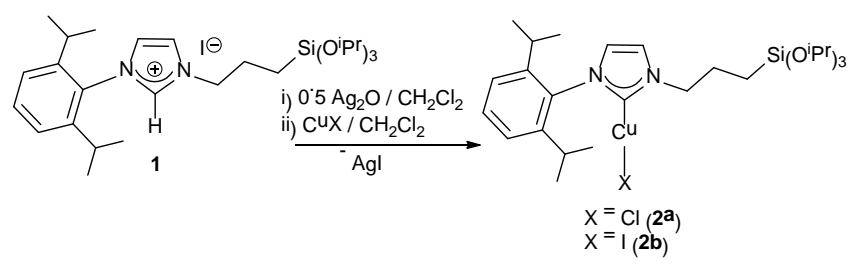

Scheme 1. Synthesis of Cu-NHC species 2.

Species 2 have been characterized by means of ${ }^{1} \mathrm{H},{ }^{13} \mathrm{C}\left\{{ }^{1} \mathrm{H}\right\}$ and ${ }^{29} \mathrm{Si}\left\{{ }^{1} \mathrm{H}\right\}$ NMR spectroscopy and mass spectrometry $\left(\mathrm{ES}^{+}\right)$. The mononuclear structure of these $\mathrm{Cu}-\mathrm{NHC}$ species has been corroborated by X-ray diffraction studies on single crystals of complex $\mathbf{2 b}$ grown in pentane solution (Figure 1). Although the structural parameters obtained from the X-ray analysis are of limited accuracy as a consequence of the weakly diffracting sample (see Experimental Section), the refined structure reveals the chemical connectivity and the molecularity of the complex. It 
is worth mentioning that rich coordination chemistry and a high structural diversity have been observed for [Cul(NHC)] based complexes. In particular, they have shown to form monomeric entities ${ }^{[8]}$ dimers with bridging iodine atoms ${ }^{[8,9]}$ or $\mathrm{NHC}$ ligands ${ }^{[8 c]}$ and trimers with both iodine and $\mathrm{NHC}$ fragments connecting the copper atoms. ${ }^{[8 c]}$

The mononuclear structure of $\mathbf{2} \mathbf{b}$ is depicted in Figure 1 , together with the most representative bond lengths and angles. The copper(I) center displays a slightly distorted linear environment with a $\mathrm{C}(1)-\mathrm{Cu}-\mathrm{I}$ angle of $175.5(5)^{\circ}$. The $\mathrm{C}(1)-\mathrm{Cu}$ and $\mathrm{Cu}-\mathrm{I}$ bond distances of 1.937(18) and 2.418(2) $\AA$ respectively, are in the range of those found for analogous $[\mathrm{Cul}(\mathrm{NHC})]$ species. ${ }^{[8]}$ The aryl group is located almost perpendicular to the imidazole backbone plane, forming a dihedral angle of $85.8(6)^{\circ}$. This geometrical disposition, minimizing the steric repulsion with the metal center, is quite common in monomeric $\mathrm{Cu}-\mathrm{NHC}$ complexes with aryl wingtip $\mathrm{N}$ substituents. ${ }^{[10]}$

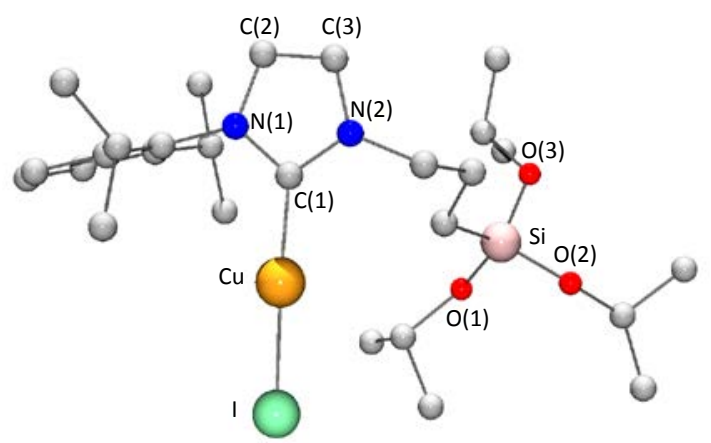

Figure 1. Molecular diagram of complex $\mathbf{2 b}$. Selected bond lengths $(\AA)$ and angles ('): Cu-I, 2.418(2); Cu-C(1), 1.937(18); C(1)-Cu-I, 175.5(5); N(1)-C(1)$N(2), 105.5(14)$.

${ }^{1} \mathrm{H}$ NMR spectra of $\mathrm{CD}_{2} \mathrm{Cl}_{2}$ solutions of complexes $\mathbf{2} \mathbf{a}$ and $\mathbf{2} \mathbf{b}$ evidenced the presence of the $-\left(\mathrm{CH}_{2}\right)_{3} \mathrm{Si}(\mathrm{OiPr})_{3}$ moiety. The characteristic resonance due to the $\mathrm{CH}_{2} \mathrm{Si}$ protons appears as a multiplet at around $\delta 0.60 \mathrm{ppm}$. The ${ }^{13} \mathrm{C}\left\{{ }^{1} \mathrm{H}\right\}$ NMR spectra of species 2a show a sharp resonance at $\delta 178.7 \mathrm{ppm}$ assigned to the carbon atom of the $\mathrm{NHC}$ ligand bonded to the copper atom. The ${ }^{13} \mathrm{C}\left\{{ }^{1} \mathrm{H}\right\}$ NMR spectra of species $\mathbf{2} \mathbf{b}$ exhibit the resonance corresponding to that carbon atom as a weak signal at $\delta 180.7$ ppm. ${ }^{[2-4]}$ The remaining resonances of the ${ }^{1} \mathrm{H},{ }^{13} \mathrm{C}\left\{{ }^{1} \mathrm{H}\right\}$ and ${ }^{29} \mathrm{Si}\left\{{ }^{1} \mathrm{H}\right\}$ NMR spectra of complexes $\mathbf{2 a}$ and $\mathbf{2 b}$ are consistent with solid state structure found for $\mathbf{2 b}$ (see Experimental Section).

Immobilization of complex 2a in MCM-41. Compound 2a was covalently anchored into MCM-41 by refluxing a suspension of commercial MCM-41 in a toluene solution of $2 \mathrm{a}$ for $22 \mathrm{~h}$ (Scheme 2). The resulting copper-NHC containing mesoporous material, 2-MCM-41, was isolated as an off-white solid and characterized by ICP-MS, ${ }^{13} \mathrm{C}$ and ${ }^{29} \mathrm{Si}$ CP-MAS NMR and TEM.
The material 2-MCM-41 has a copper loading of $0.15 \mathrm{mmol}$ of $\mathrm{Cu} \mathrm{g}^{-1}$. The most prominent resonances in the ${ }^{13} \mathrm{C}$ CP-MAS solid state NMR spectra of the solids are those due to the aromatic carbon atoms of the 2,6-diisopropylphenyl $\mathrm{N}$-substituent, which appear as broad resonances at $\delta 145$ and $130 \mathrm{ppm}$, a broad resonance at $\delta 123 \mathrm{ppm}$ assigned to the $\mathrm{CH}_{\text {imd }}$ and broad resonances at $\delta 52 \mathrm{ppm}$ and at $\delta 8.1 \mathrm{ppm}$ due to the $\mathrm{CH}_{2} \mathrm{~N}$ and $\mathrm{CH}_{2} \mathrm{Si}$ carbon atoms, respectively. The ${ }^{29} \mathrm{Si}$ CP-MAS solid state NMR spectra of 2-MCM-41 exhibit resonances of great intensity corresponding to the silicon atoms of the silica (at around $\delta-91.0$, -100 and $-108 \mathrm{ppm}$ ) and a less intense broad resonance at around $\delta-54 \mathrm{ppm}$ assigned to $\mathrm{T}^{\mathrm{n}}$ environments of the $\mathrm{CH}_{2} \mathrm{Si}$ silicon atoms. ${ }^{[11]}$

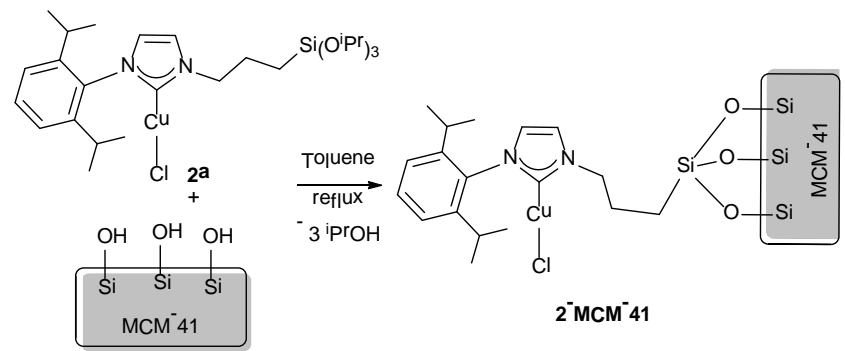

Scheme 2. Synthesis of 2-MCM-41.

The transmission electron microscopy (TEM) of 2-MCM-41 shows that the new material keeps the long-range ordering of hexagonal symmetry with regular, monodirectional channels of the parent MCM-41 (Figure 2). In addition, the only particles that we were able to detect by TEM correspond to MCM-41 and no evidence of metallic Cu-particles was observed. This fact constitutes further evidence of the covalent anchoring of the $\mathrm{Cu}$ $\mathrm{NHC}$ molecules to MCM-41.
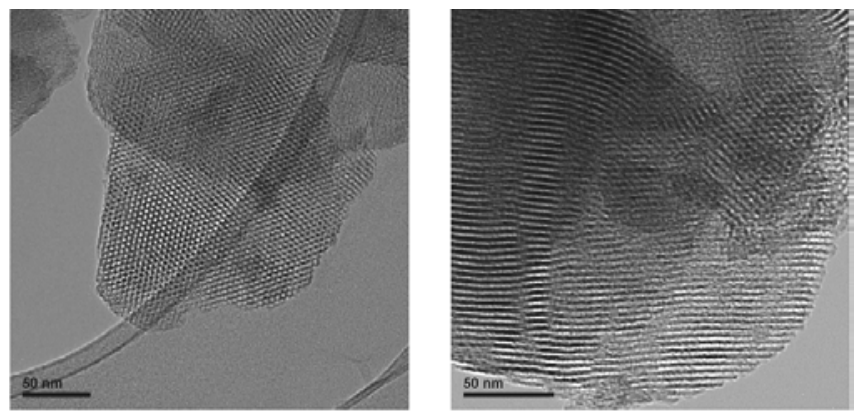

Figure 2. Transmission electron microscopy (TEM) of 2-MCM-41.

The results of $\mathrm{N}_{2}$-physisorption/desorption studies of 2-MCM-41 indicate that the surface area, pore volume and pore size are smaller than the corresponding values found for the starting MCM-41 (Table 1), which suggest the inclusion of the Cu-NHC species inside the channels of the mesoporous material. 
Table 1. $\mathrm{N}_{2}$-physisorption/desorption studies.

\begin{tabular}{lcccc|} 
Material & {$[\mathrm{Cu}]^{[\mathrm{a}]}$} & $\mathrm{S}_{\mathrm{BET}}^{[\mathrm{b}]}$ & $\mathrm{Vp}^{[\mathrm{c}]}$ & $\mathrm{Dp}^{[\mathrm{d}]}$ \\
\hline MCM-41 & - & 958.78 & 0.9084 & 37.89 \\
2-MCM-41 & 0.15 & 827.44 & 0.7783 & 37.62
\end{tabular}

[a] $\mathrm{mmol} \mathrm{g}^{-1}$ from ICP analysis. [b] Surface area, $\mathrm{m}^{2} \mathrm{~g}^{-1}$. [c] Pore volume, $\mathrm{cm}^{3} \mathrm{~g}^{-1}$. [d] Pore size, $\AA$.

Homogeneous hydrosilylation of acetophenone with $\mathrm{HSiEt}_{3}$ using $2 \mathbf{a}$ as catalyst precursor. It has been proposed that the co-catalyst, Lewis base (LB), in Cu-NHC based ketones hydrosilylation processes plays a role not only in the activation of the catalyst precursor but also promoting the $\mathrm{Si}-\mathrm{H}$ bond activation via the in-situ generation of active pentavalent silicon species. ${ }^{[5]}$ Indeed, most of the reported examples of catalytic systems based on mononuclear $[\mathrm{Cu}(\mathrm{Cl})(\mathrm{NHC})]$ complexes, which have proven to be effective for such reaction, used a large excess (10-25 mol\%) of the corresponding LB (RO- or $\left.\mathrm{F}^{-}\right) .^{[2-5]}$ In this context, we have carried out preliminary studies on the catalytic activity of complex $\mathbf{2 a}$ for the homogeneous hydrosilylation of acetophenone with $\mathrm{HSiEt}_{3}$, with the aim of reducing to a minimum the amount of co-catalyst. As a result of these studies we have found that a catalyst concentration of 5.0 $\mathrm{mol} \%$ and a co-catalyst/catalyst ratio of $1.5 / 1$ was enough to produce a reasonably active catalytic system. Thus, the reaction of toluene solutions of acetophenone with $\mathrm{HSiEt}_{3}$ in presence of catalytic amounts of complex $2 \mathrm{a}(5.0 \mathrm{~mol} \%)$ and $\mathrm{KOtBu}(7.5$ mol\%) allows the full conversion of acetophenone into the expected hydrosilylation product, which was characterized by means of ${ }^{1} \mathrm{H}$ NMR spectroscopy, after 18 hours at room temperature (Scheme 3).

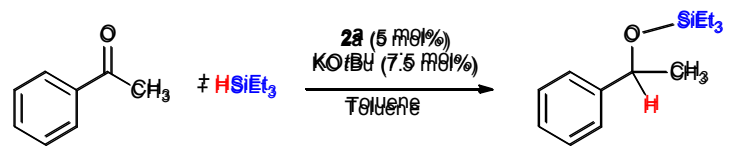

Scheme 3. Catalytic hydrosilylation of acetophenone with $\mathrm{HSiEt}_{3}$.

A variable temperature study of the above described catalytic reaction (Scheme 3) in $\mathrm{C}_{6} \mathrm{D}_{6}$ in presence of $\mathbf{2 a}(5.0 \mathrm{~mol} \%)$ and $\mathrm{KOtBu}(7.5 \mathrm{~mol} \%)$ showed the positive effect of the temperature on the catalytic activity of $\mathbf{2 a}$ (Figure 3). Indeed, at $343 \mathrm{~K}$ the full conversion of acetophenone into the hydrosilylation product was achieved after 5 hours.

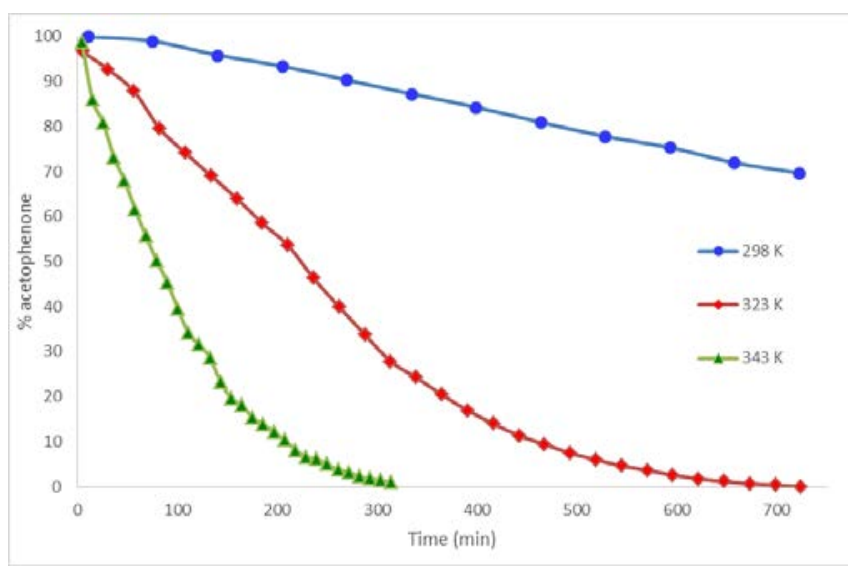

Figure 3. Representation of the concentration of acetophenone (\%) versus time (min) for the catalytic hydrosilylation of acetophenone with $\mathrm{HSiEt}_{3}$ in $\mathrm{C}_{6} \mathrm{D}_{6}$ using complex $2 \mathrm{a}$ as catalyst precursor $(5.0 \mathrm{~mol} \%)$ and KOtBu $(7.5 \mathrm{~mol} \%)$ as co-catalyst at different temperatures.

Hydrosilylation of acetophenone with $\mathrm{HSiEt}_{3}$ using 2-MCM41 as heterogeneous catalyst. There is an increasing interest on the immobilization of homogeneous catalysts onto supports producing heterogeneous catalysts that could be easily separated from the reaction products. Particularly, $\mathrm{Si}(\mathrm{OR})_{3^{-}}$ functionalyzed metal-NHC species have proven to be useful for its grafting on $\mathrm{Si}-\mathrm{OH}$ functionalized mineral supports. ${ }^{[12]}$ However, only a few examples of $\mathrm{Cu}-\mathrm{NHC}$ based supported catalysts have been reported so far. ${ }^{[13]}$ In this regard, it should be mentioned that we have recently developed a new family of Rh-NHC based homogeneous catalysts, with (iPrO) ${ }_{3}$ Si-functionalized $\mathrm{NHC}$ ligands, which have shown to be accurate models for the activity of the related Rh-NHC based supported catalysts in the catalytic hydrosilylation of ketones. ${ }^{[7,14]}$

However, in contrast to what was observed for $\mathbf{2 a}$, the material 2-MCM-41, which is supposed to contain $[\mathrm{Cu}(\mathrm{Cl})(\mathrm{NHC})]$ moieties covalently bonded to the surface of the solid through Si-O-Si bridges, shows no activity for the catalytic hydrosilylation of acetophenone with $\mathrm{HSiEt}_{3}$. Indeed, we have observed that acetophenone and $\mathrm{HSiEt}_{3}$ did not react in presence of catalytic amounts of 2-MCM-41 (5.0 mol\% of copper) in THF (at $70^{\circ} \mathrm{C}$ ), toluene $\left(100{ }^{\circ} \mathrm{C}\right)$, neither in 1,4-dioxane (at $\left.120^{\circ} \mathrm{C}\right)$ nor in the presence of a large excess of KOtBu. It should be mentioned that this catalytic system remains inactive even in the presence of other basic co-catalysts as for instance $\mathrm{Cs}_{2} \mathrm{CO}_{3}$ and $\mathrm{CsOH}$, which is certainly an unexpected result.

The above described findings might raise some doubts about the nature of the copper sites at the surface of 2-MCM-41. Therefore, to shed light on the accessibility of the Cu-NHC active sites, we have studied the activity of 2-MCM-41 as catalyst for cycloaddition reactions (Scheme 4).

1,3-Dipolar cycloaddition of benzyl azide to phenylacetylene catalyzed by $2 \mathrm{a}$ and $2-\mathrm{MCM}-\mathbf{4 1}$. It has been established that copper(I) species are efficient catalysts for the Huisgen 1,3dipolar cycloaddition of azides and alkynes. ${ }^{[15,16]}$ Thus, the reaction of $\mathrm{CH}_{2} \mathrm{Cl}_{2}$ solutions of benzyl azide with 
phenylacetylene in the presence of catalytic amounts of $\mathbf{2 a}(5.0$ mol\%) at $298 \mathrm{~K}$ yields quantitatively the expected [1,2,3]-triazol after 7 hours of reaction (Scheme 4 and Table 2), which has been characterized by comparison of its ${ }^{1} \mathrm{H}$ NMR $\left(\mathrm{CD}_{3} \mathrm{Cl}\right)$ spectra with the reported data. ${ }^{[17]}$

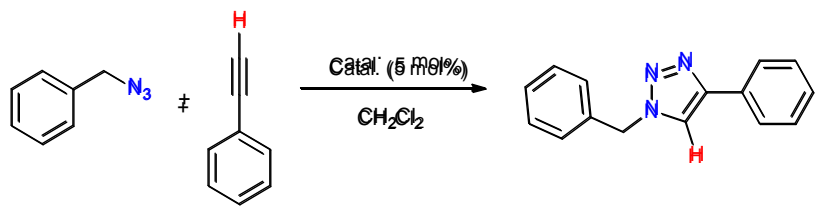

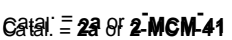

Scheme 4. Catalytic [3+2] cycloaddition of benzyl azide with phenylacetylene.

\begin{tabular}{|c|c|c|}
\hline Catalyst (5 mol\%) & Time (h) & Conversion (\%) ${ }^{[\mathrm{a}]}$ \\
\hline $2 a$ & 7 & 99 \\
\hline 2-MCM-41 (fresh) & 7 & 86 \\
\hline 2-MCM-41 (fresh) & 24 & 99 \\
\hline 2-MCM-41 (1-cycle) & 24 & 99 \\
\hline 2-MCM-41 (2-cycle) & 24 & 99 \\
\hline 2-MCM-41 (3-cycle) & 24 & 68 \\
\hline 2-MCM-41 (4-cycle) & 24 & 42 \\
\hline rolculato & $\begin{array}{l}\text { VMR inte } \\
\text { sonances }\end{array}$ & of the benzyl \\
\hline
\end{tabular}

It should be mentioned that some examples of $\mathrm{Cu}-\mathrm{NHC}$ based heterogeneous systems effective for [3+2] cycloaddition of azides and alkynes have been recently reported. ${ }^{[13 a, d, e, f, g]}$ In our particular case, the reaction of $\mathrm{CH}_{2} \mathrm{Cl}_{2}$ solutions of benzyl azide with phenylacetylene in the presence of catalytic amounts of the solid 2-MCM-41 (5.0 mol\% in $\mathrm{Cu}$ ) at $298 \mathrm{~K}$ affords the expected cycloaddition product, which was quantitatively obtained after 24 hours. Therefore, the heterogeneous catalyst 2-MCM-41 has shown to be less active than the homogenous catalytic system based on 2a. In addition, it should be mentioned that the heterogeneous catalyst could be used after recycling, maintaining the catalytic activity for two cycles (Table 2). However, a decrease of the catalytic activity was observed after three cycles, which is attributable to the diminishing of $\mathrm{Cu}$-active species at the surface of the heterogeneous catalyst due to leaching processes. Indeed, ICP analysis of 2-MCM-41 samples after being used four times as catalyst for the Huisgen reaction showed a copper loading of $0.08 \mathrm{mmol}$ of $\mathrm{Cu} \mathrm{\textrm {g } ^ { - 1 }}$, which represents a loss of $53 \%$ of the copper with respect to the $\mathrm{Cu}$ present in the fresh material (Table 1).

It is worth mentioning that 2-MCM-41 samples, recovered from the unsuccessful catalytic studies of acetophenone hydrosilylation with $\mathrm{HSiEt}_{3}$, have proven to be active catalysts for the Huisgen 1,3-dipolar cycloaddition of benzyl azides and phenylacetylene leading to the corresponding triazol with a conversion ca. $97 \%$ after $24 \mathrm{~h}$.

Liu and Harrod reported in 1990 that the reaction of copperalkynyl species with silanes to afford the corresponding $\mathrm{Cu}-\mathrm{H}$ intermediate and the corresponding alkynyl silane was the determinant step in the copper mediated dehydrocoupling reaction between hydrosilanes and phenylacetylene. ${ }^{[18]}$ In this context, it its worth noting that copper-acetylide intermediates have been proposed as active species for the copper-catalyzed Huisgen reaction. ${ }^{[15,16]}$ Therefore, it is reasonable to asume that the reaction of 2-MCM-41 samples, recycled from the Huisgen reaction, with $\mathrm{HSiEt}_{3}$ could afford 2-MCM-41 samples, containing $\mathrm{Cu}-\mathrm{H}$ functionalities, which could be active catalysts for acetophene hydrosilylation. However, these heterogeneous catalysts recycled from the Huisgen reaction showed no activity in acetophenone hydrosilylation with $\mathrm{HSiEt}_{3}$, neither in presense nor in absence of KOtBu.

The above described facts evidenced that the copper centers at the surface of the supported catalyst samples, are accessible to the reagents of the Huisgen reaction, phenylacetylene and benzyl azide. However, all the tested samples of 2-MCM-41 (fresh and recycled) were not active for hydrosilylation. In this regard, it should be mentioned that Cu-OR species, similar to those postulated as intermediates in Cu-catalyzed ketones hydrosilylation processes, ${ }^{[2-5]}$ interact with the $\mathrm{Si}-\mathrm{OH}$ groups present at the surface of MCM-41 and related mesoporous silica. ${ }^{[19]}$ Therefore, the lack of activity as hydrosilylation catalyst shown by 2-MCM-41 could be attributed to effects of the support on the chemistry of the grafted copper species.

\section{Conclusions}

The complexes $\quad[\mathrm{Cu}(\mathrm{X})(2,6$-diisopropylphenyl-NHC$\left.\left.\left(\mathrm{CH}_{2}\right)_{3} \mathrm{Si}(\mathrm{OiPr})_{3}\right)\right](\mathrm{X}=\mathrm{Cl}, \mathbf{2 a} ; \mathbf{I}, \mathbf{2} \mathbf{b})$ have been prepared. Furthermore, the structure of $\mathbf{2} \mathbf{b}$ has been confirmed by $\mathrm{X}$-ray diffraction studies. Complex $\mathbf{2} \mathbf{a}$ has been successfully anchored in MCM-41 to afford 2-MCM-41. The activity of both the homogeneous, $\mathbf{2 a}$, and heterogeneous, 2-MCM-41, catalysts in acetophenone hydrosilylation with $\mathrm{HSiEt}_{3}$ and 1,3-Dipolar cycloaddition of benzyl azide to phenylacetylene has been investigated. The homogeneous catalyst has shown to be more active than its heterogeneous counterpart in both processes. Moreover, it should be mentioned that the heterogeneous catalyst exhibits catalytic activity for the cycloaddition reaction though, unexpectedly, showed no catalytic activity for hydrosilylation, which could be attributed to effects of the support on the behavior of the anchored copper species.

\section{Experimental Section}

General information. All manipulations were performed with rigorous exclusion of air at an argon/vacuum manifold using standard Schlenk tube techniques or in a dry-box (MB-UNILAB). Solvents were dried by the usual procedures and distilled under argon prior to use or taken under argon from a Solvent Purification System (SPS). The reagents 
triethylsilane, acetophenone, benzyl azide, phenylacetylene and the solid MCM-41 were purchased from commercial sources. The imidazolium salt 1 was prepared according to methods reported in the literature. ${ }^{[7]} \mathrm{NMR}$ spectra were recorded on a Varian Gemini 2000, Bruker ARX 300, Bruker Avance $300 \mathrm{MHz}$ or Bruker Avance $400 \mathrm{MHz}$ instrument. Chemical shifts (expressed in parts per million) are referenced to residual solvent peaks $\left({ }^{1} \mathrm{H},{ }^{13} \mathrm{C}\left\{{ }^{1} \mathrm{H}\right\}\right)$. Coupling constants, J, are given in hertz. C, $\mathrm{H}$, and $\mathrm{N}$ analyses were carried out in a Perkin-Elmer $2400 \mathrm{CHNS} / \mathrm{O}$ analyzer. Mass spectrometry was measured on an Esquire 3000+ with Ion trap detector interfaced to an Agilent 1100 series HPLC system. TEM microscopy images were collected using INCA $200 \mathrm{X}$-Sight from Oxford Instruments with a resolution in energy between $136 \mathrm{eV}$ and $5.9 \mathrm{KeV}$. Isotherms were obtained on a Quantachrome AUTOSORB by measuring the volume of $\mathrm{N}_{2}$ absorbed at relative pressures between 0.05 and 0.99 at $77.3 \mathrm{~K}$ after drying the sample at $120^{\circ} \mathrm{C}$ in vacuo. Surface Area Data, pore volume data and pore size data were obtained by Non Localized Density Functional Theory (NLDFT) method.

\section{Preparation of [1-(2,6-diisopropylphenyl)-3-(3-} triisopropoxysilylpropyl)-imidazol-2-yl]copper(I) chloride (2a). In-situ preparation of the silver-NHC species: A suspension of silver(I) oxide $(0.097 \mathrm{~g}, 0.42 \mathrm{mmol})$ and salt $1(0.460 \mathrm{~g}, 0.76 \mathrm{mmol})$ in a mixture of dichloromethane and acetonitrile (ratio 9:1, $10 \mathrm{~mL}$ ) was stirred for $20 \mathrm{~h}$ at room temperature in the absence of light. The solvent was removed and dichloromethane $(15 \mathrm{~mL})$ was added to the reaction mixture. Then, the crude reaction mixture was passed through a short pad of silica in the glove box, eluting with dichloromethane and the filtrate was evaporated to dryness. The addition of cold hexane $\left(0{ }^{\circ} \mathrm{C}, 4 \mathrm{~mL}\right)$ caused the precipitation of a white solid, which was separated by decantation, washed with cold hexane $\left(0^{\circ} \mathrm{C}, 2 \times 2 \mathrm{~mL}\right)$ and dried in vacuo. Yield $0.315 \mathrm{~g}$ (58 \%). Copper(I) chloride (0.044 g, $0.45 \mathrm{mmol})$ and dichloromethane $(8 \mathrm{~mL})$ were added to the in-situ generated silver-NHC species $(0.315 \mathrm{~g}, 0.45 \mathrm{mmol})$. The resulting suspension was stirred for 4 $\mathrm{h}$ at room temperature in the absence of light. After that, the resulting solution was filtered through Celite, and the solvent removed in vacuo. The addition of hexane $(3 \mathrm{~mL})$ at $0{ }^{\circ} \mathrm{C}$ led to a white solid, which was separated by decantation, washed with pentane $(2 \times 2.5 \mathrm{~mL})$ at $0{ }^{\circ} \mathrm{C}$ and and dried in vacuo. Yield: $0.191 \mathrm{~g}(75 \%)$. Mass spectrometry (ESI): $\mathrm{m} / \mathrm{z}$ 1011.5, $\left[\mathrm{Cu}(\mathrm{NHC})_{2}\right]^{+}(100 \%) ; 537.2,[\mathrm{M}-\mathrm{Cl}]^{+}(30 \%) .{ }^{1} \mathrm{H}$ NMR $(300.13$ $\left.\mathrm{MHz}, \mathrm{CD}_{2} \mathrm{Cl}_{2}, 298 \mathrm{~K}\right): \delta 7.50\left(\mathrm{t}, \mathrm{J}_{\mathrm{H}-\mathrm{H}}=7.8,1 \mathrm{H}, \mathrm{o}-\mathrm{H}_{\mathrm{Ph}}\right), 7.30\left(\mathrm{~d}, \mathrm{~J}_{\mathrm{H}-\mathrm{H}}=7.8\right.$, $2 \mathrm{H}, m-\mathrm{H}_{\mathrm{Ph}}$ ), 7.17 and 6.95 (both d, $\mathrm{J}_{\mathrm{H}-\mathrm{H}}=1.8,2 \mathrm{H}, \mathrm{CH}_{\text {imid }}$ ), 4.26 (t, $\mathrm{J}_{\mathrm{H}-\mathrm{H}}=$ $6.9,2 \mathrm{H}, \mathrm{NCH}_{2}$ ), 4.21 (sept, $J_{\mathrm{H}-\mathrm{H}}=6.1,3 \mathrm{H}, \mathrm{CH}-\mathrm{O}^{\prime} \mathrm{Pr}$ ), 2.41 (sept, $J_{\mathrm{H}-\mathrm{H}}=$ $\left.6.9,2 \mathrm{H}, \mathrm{CH}-{ }^{i} \mathrm{Pr}\right), 2.07-1.94\left(\mathrm{~m}, 2 \mathrm{H},-\mathrm{CH}_{2}-\right), 1.24\left(\mathrm{~d}, \mathrm{~J}_{\mathrm{H}-\mathrm{H}}=6.9,6 \mathrm{H}, \mathrm{CH}_{3-}\right.$ $\left.{ }^{i} \mathrm{Pr}\right), 1.19\left(\mathrm{~d}, \mathrm{~J}_{\mathrm{H}-\mathrm{H}}=6.1,18 \mathrm{H}, \mathrm{CH}_{3}-\mathrm{O}^{\prime} \mathrm{Pr}\right), 1.13\left(\mathrm{~d}, \mathrm{~J}_{\mathrm{H}-\mathrm{H}}=6.9 \mathrm{~Hz}, 6 \mathrm{H}, \mathrm{CH}-\right.$ $\left.{ }^{i} \mathrm{Pr}\right), 0.64-0.53\left(\mathrm{~m}, 2 \mathrm{H}, \mathrm{CH}_{2} \mathrm{Si}\right) .{ }^{13} \mathrm{C}\left\{{ }^{1} \mathrm{H}\right\}-\mathrm{APT}$ NMR plus $\mathrm{HMBC}$ and HSQC (75.5 MHz, $\left.\mathrm{CD}_{2} \mathrm{Cl}_{2}, 298 \mathrm{~K}\right): \delta 178.7$ (s, C-Cu), 146.5 (s, C-'PrPh), $135.4\left(\mathrm{~s}, \mathrm{C}_{\mathrm{ppso}} \mathrm{Ph}\right), 130.8\left(\mathrm{~s}, o-\mathrm{C}_{\mathrm{ph}}\right), 124.6\left(\mathrm{~s}, \mathrm{~m}-\mathrm{C}_{\mathrm{Ph}}\right), 123.9$ and 121.1 (both s, $\mathrm{CH}_{\text {imid }}$ ), 65.7 (s, $\mathrm{CH}-\mathrm{O}^{i} \mathrm{Pr}$ ), $54.3\left(\mathrm{~s}, \mathrm{NCH}_{2}\right), 28.9\left(\mathrm{~s}, \mathrm{CH}^{-}{ }^{-} \mathrm{Pr}\right), 26.2$ (s, - $\mathrm{CH}_{2}$ ), 26.0 (s, $\mathrm{CH}_{3}-\mathrm{O}^{\prime} \mathrm{Pr}$ ), 24.9 and 24.5 (both s, $\mathrm{CH}_{3}{ }^{-} \mathrm{Pr}$ ), 9.5 (s, $\left.\mathrm{CH}_{2} \mathrm{Si}\right) .{ }^{29} \mathrm{Si}\left\{{ }^{1} \mathrm{H}\right\}$ NMR $\left(59.6 \mathrm{MHz}, \mathrm{CD}_{2} \mathrm{Cl}_{2}, 298 \mathrm{~K}\right): \delta-51.5\left(\mathrm{~s}, \mathrm{CH}_{2} \mathrm{Si}\right)$.

\section{Preparation of [1-(2,6-diisopropylphenyl)-3-(3-} triisopropoxysilylpropyl)-imidazol-2-yl]copper(l) iodide (2b). The procedure was similar to the above described for complex $\mathbf{2} \mathbf{a}$ but using copper(I) iodide $(0.086 \mathrm{~g}, 0.45 \mathrm{mmol})$, instead of copper $(\mathrm{I})$ chloride. The reaction mixture was stirred for $20 \mathrm{~h}$ in absence of light. The resulting solution was filtered through Celite, and the solvent removed in vacuo. The addition of cold pentane $\left(-78^{\circ} \mathrm{C}, 3 \mathrm{~mL}\right)$ led to a light yellow solid, which was separated by decantation, washed with further portions of cold pentane $\left(-78^{\circ} \mathrm{C}, 3 \times 2.5 \mathrm{~mL}\right)$ and dried in vacuo. Yield: $0.134(50 \%)$. The relatively low isolated yield, in comparison to that obtained for $\mathbf{2 a}$, is supposed to be a consequence of the high solubility of $\mathbf{2} \mathbf{b}$. Anal. calcd. for $\mathrm{C}_{27} \mathrm{H}_{46} \mathrm{~N}_{2} \mathrm{CulO}_{3} \mathrm{Si}$ (665.21): C, 48.75; H, 6.97; N, 4.21. Found: C, 49.30; $\mathrm{H}, \quad 7.52 ; \mathrm{N}, \quad 4.50$. Mass spectrometry (ESI): $\mathrm{m} / \mathrm{z}$ 1011.7,
$\left[\mathrm{Cu}(\mathrm{NHC})_{2}\right]^{+}(100 \%) ; 537.3,[\mathrm{M}-\mathrm{I}]^{+}(20 \%) .{ }^{1} \mathrm{H}$ NMR $\left(300.13 \mathrm{MHz}, \mathrm{CD}_{2} \mathrm{Cl}_{2}\right.$ $298 \mathrm{~K}): \delta 7.50\left(\mathrm{t}, \mathrm{J}_{\mathrm{H}-\mathrm{H}}=7.8,1 \mathrm{H}, o-\mathrm{H}_{\mathrm{Ph}}\right), 7.30\left(\mathrm{~d}, \mathrm{~J}_{\mathrm{H}-\mathrm{H}}=7.8,2 \mathrm{H}, m-\mathrm{H}_{\mathrm{Ph}}\right)$ 7.17 and 6.96 (both d, $J_{\mathrm{H}-\mathrm{H}}=1.8,2 \mathrm{H}, \mathrm{CH}_{\text {imid }}$ ), $4.26\left(\mathrm{t}, \mathrm{J}_{\mathrm{H}-\mathrm{H}}=6.9,2 \mathrm{H}\right.$, $\mathrm{NCH}_{2}$ ), 4.21 (sept, $\mathrm{J}_{\mathrm{H}-\mathrm{H}}=6.0,3 \mathrm{H}+2 \mathrm{H}, \mathrm{CH}-\mathrm{O}^{\prime} \mathrm{Pr}$, the signal corresponding to the $-\mathrm{NCH}_{2}$ protons overlapped with the multiplet corresponding to the $\mathrm{CH}-\mathrm{O}^{i} \mathrm{Pr}$ protons), 2.40 (sept, $\mathrm{J}_{\mathrm{H}-\mathrm{H}}=6.9,2 \mathrm{H}, \mathrm{CH}^{-} \mathrm{Pr}$ ), $2.06-1.90\left(\mathrm{br}, 2 \mathrm{H},-\mathrm{CH}_{2}-\right), 1.23\left(\mathrm{~d}, \mathrm{~J}_{\mathrm{H}-\mathrm{H}}=6.9,6 \mathrm{H}, \mathrm{CH}_{3}{ }^{i} \mathrm{Pr}\right), 1.19\left(\mathrm{~d}, \mathrm{~J}_{\mathrm{H}-\mathrm{H}}\right.$ $\left.=6.0,18 \mathrm{H}, \mathrm{CH}_{3}-\mathrm{O}^{\prime} \mathrm{Pr}\right), 1.12\left(\mathrm{~d}, \mathrm{~J}_{\mathrm{H}-\mathrm{H}}=6.9,6 \mathrm{H}, \mathrm{CH}^{-}{ }^{\mathrm{P}} \mathrm{Pr}\right), 0.60-0.50(\mathrm{br}$, $\left.2 \mathrm{H}, \mathrm{CH}_{2} \mathrm{Si}\right) .{ }^{13} \mathrm{C}\left\{{ }^{1} \mathrm{H}\right\}-\mathrm{APT}$ NMR plus HMBC and HSQC $(75.5 \mathrm{MHz}$, $\mathrm{CD}_{2} \mathrm{Cl}_{2}, 298 \mathrm{~K}$ ): $\delta 180.7$ (br, low intensity, C-Cu), 146.5 (s, C- ${ }^{i} \mathrm{PrPh}$ ) 135.3 (s, $\mathrm{C}_{\text {ipso }} \mathrm{Ph}$ ), $130.8\left(\mathrm{~s}, o-\mathrm{C}_{\mathrm{Ph}}\right), 124.6\left(\mathrm{~s}, \mathrm{~m}-\mathrm{C}_{\mathrm{Ph}}\right), 123.9$ and 121.1 (both s, $\mathrm{CH}_{\text {imid }}$ ), 65.7 (s, CH-O'Pr), 54.0 (s, NCH ), 28.9 (s, CH- $\left.{ }^{i} \mathrm{Pr}\right), 26.1$ (s, - $\mathrm{CH}_{2-}$ ), 26.0 (s, $\mathrm{CH}_{3}-\mathrm{O}^{\prime} \mathrm{Pr}$ ), 25.0 and 24.5 (both s, $\mathrm{CH}_{3}{ }^{i} \mathrm{Pr}$ ), 9.5 (s, $\left.\mathrm{CH}_{2} \mathrm{Si}\right) .{ }^{29} \mathrm{Si}\left\{{ }^{1} \mathrm{H}\right\}$ NMR $\left(59.6 \mathrm{MHz}, \mathrm{CD}_{2} \mathrm{Cl}_{2}, 298 \mathrm{~K}\right): \delta-50.3\left(\mathrm{~s}, \mathrm{CH}_{2} \mathrm{Si}\right)$.

X-ray crystal structure determination. X-ray data collection was carried out at $100(2) \mathrm{K}$ with graphite-monochromated $\mathrm{MoK}_{\alpha}$ radiation $(\lambda=$ $0.71073 \AA$ ), using narrow rotation $\left(0.3^{\circ}\right)$ on a Bruker SMART APEX CCD diffractometer. Intensities were integrated using SAINT+ program ${ }^{[20]}$ and corrected for absorption effects using SADABS program ${ }^{[21]}$ integrated into APEX2 package. The structure was solved by direct methods using SHELXS-97..$^{[22,23]}$ Refinement by full-matrix least-squares on $F^{2}$ was performed using SHELXL-2014. ${ }^{[24]}$

Crystal data for 2b. $\mathrm{C}_{27} \mathrm{H}_{46} \mathrm{CuIN}_{2} \mathrm{O}_{3} \mathrm{Si}$, colorless plate, $0.052 \times 0.083 \times$ $0.169 \mathrm{~mm}^{3}$, triclinic, $P-1, a=8.4479(18) \AA, b=9.435(2) \AA, c=23.652(5) \AA$, $\alpha=94.178(3)^{\circ}, \beta=98.830(3)^{\circ}, \gamma=110.596(2)^{\circ}, Z=2, V=1727.3(6) \AA^{3}$, $\rho_{\text {cal }}=1.279 \mathrm{~g} \mathrm{~cm}^{-3}, \mu=1.586 \mathrm{~cm}^{-1}$, min. and max. correction factors 0.474 and $0.809 ; 2 \theta_{\max }=42.59^{\circ} ; 11001$ collected reflections, 3797 unique $\left[R_{\text {int }}=0.125\right]$; number of data/restraints/parameters 3797/0/202; final GoF 1.069; $R_{1}=0.101$ [2388 reflections with $\left.>2 \sigma(I)\right] ; w R_{2}=0.252$ for all data; the largest difference peak: 2.009 e $\AA^{-3}$. The compound crystallizes in tiny plates, mutually stuck. Several samples were tried before selecting the one used in the data collection. Split reflections were observed in their diffraction pattern, revealing the presence of a twin. Moreover, the crystals are air-sensitive and became quickly degraded. Eventually, a narrow plate with isolated and well defined Bragg peaks was selected, showing no detectable intensity over $2 \theta=42.6^{\circ}$. Therefore this value was used as cut-off in the integration process. Due to the limited quality of data, only $\mathrm{Cu}, \mathrm{Cl}, \mathrm{Si}, \mathrm{O}$ and $\mathrm{N}$ atoms have been refined with a thermal anisotropic model. Two methyl groups of an isopropyl fragment have been found to be disordered. They have been included in the model in two sets of positions and refined with complementary occupancy factors $(0.61 / 0.39(6))$.

CCDC: 1053714 contain the supplementary crystallographic data for complex $\mathbf{2 b}$. These data can be obtained free of charge from the Cambridge Crystalographic Data Centre via www.ccdc.cam.ac.uk/data request/cif.

Immobilization of 2a on MCM-41. In a Schlenk were added the support MCM-41 $\left(1.30 \mathrm{~g}\right.$, previously degassed and heated at $130{ }^{\circ} \mathrm{C}$ for $16 \mathrm{~h}$ ), complex $2 \mathrm{a}(0.130 \mathrm{~g}, 10 \%$ in weight) and $20 \mathrm{~mL}$ of wet toluene. The mixture was stirred first at room temperature for 1 hour and then, at reflux for 22 hours. The reaction mixture was cooled to room temperature and the solid was separated by decantation, washed with dichloromethane (3 $\times 15 \mathrm{~mL})$ and diethyl ether $(3 \times 15 \mathrm{~mL})$ and dried in vacuo at $50^{\circ} \mathrm{C}$ for a night to afford an off-white solid, in almost quantitative yield (1.41g). The $\mathrm{Cu}$ loading based on the percent of metal obtained from the ICP-MS analysis was $0.15 \mathrm{mmol} \mathrm{Cu} / \mathrm{g}$.

General procedure for the homogeneous catalytic hydrosilylation of acetophenone. In a NMR tube, $2 \mathrm{a}(0.012 \mathrm{~g}, 0.02 \mathrm{mmol})$ was dissolved in benzene- $\mathrm{d}_{6}(0.4 \mu \mathrm{L})$ and treated with $0.4 \mathrm{mmol}$ of acetophenone $(47$ $\mu \mathrm{L}), 0.45 \mathrm{mmol}$ of $\mathrm{Et}_{3} \mathrm{SiH}(72 \mu \mathrm{L})$ and $0.035 \mathrm{mmol}$ of KOtBu $(0.0035 \mathrm{~g})$. 
The course of the reaction was monitored by ${ }^{1} \mathrm{H}$ NMR at different temperatures ( $298 \mathrm{~K}, 323 \mathrm{~K}$ and $343 \mathrm{~K}$ )

General procedure for the heterogeneous catalytic hydrosilylation of acetophenone. A cylindrical vessel for operating in batch mode was charged with 2-MCM-41 (0.068 g, $0.01 \mathrm{mmol}$ of $\mathrm{Cu}), 0.03 \mathrm{mmol}$ of the corresponding base ( $\mathrm{KOtBuO}, \mathrm{CsCO}_{3}, \mathrm{CsOH}, \mathrm{DABCO}$ or piperidine), 1.0 $\mathrm{mL}$ of solvent (THF, toluene or 1,4-dioxane). The resulting suspension was stirred for $2 \mathrm{~h}$ at room temperature. After which, acetophenone $(0.20$ mmol) and $\mathrm{HSiEt}_{3}(0.25 \mathrm{mmol})$ were added. The mixture was heated and stirred at $343 \mathrm{~K}$ (THF) or $373 \mathrm{~K}$ (toluene) or $393 \mathrm{~K}$ (1,4-dioxane) for $24 \mathrm{~h}$. Samples were taken and analyzed by ${ }^{1} \mathrm{H}$ NMR spectroscopy.

General procedure for the heterogeneous catalytic [3+2] cycloaddition of benzyl azide and phenylacetylene. A cylindrical vessel for operating in batch mode was charged with 2-MCM-41 (0.068 g $0.01 \mathrm{mmol}$ of $\mathrm{Cu}), 1.0 \mathrm{~mL}$ of $\mathrm{CH}_{2} \mathrm{Cl}_{2}$, benzyl azide $(0.20 \mathrm{mmol})$ and phenylacetylene $(0.20 \mathrm{mmol})$. The mixture was stirred for $24 \mathrm{~h}$ at $298 \mathrm{~K}$. The heterogeneous catalyst was decanted from the reaction mixture by centrifugation and washed twice with $\mathrm{CH}_{2} \mathrm{Cl}_{2}(2 \times 4 \mathrm{~mL})$. The $\mathrm{CH}_{2} \mathrm{Cl}_{2}$ fractions were collected and dried in vacuo to give a white residue which was analyzed by ${ }^{1} \mathrm{H}$ NMR spectroscopy. Data for 1-benzyl-4-phenyl[1,2,3]-triazol. ${ }^{1} \mathrm{H}$ NMR $\left(\mathrm{CD}_{3} \mathrm{Cl}, 300 \mathrm{MHz}\right): \delta 7.78-7.82(\mathrm{~m}, 2 \mathrm{H}, \mathrm{CH}-\mathrm{Ar})$, $7.66(\mathrm{~s}, 1 \mathrm{H}, \mathrm{NCH}), 7.44-7.28(\mathrm{~m}, 8 \mathrm{H}, \mathrm{CH}-\mathrm{Ar}), 5.58\left(\mathrm{~s}, 2 \mathrm{H}, \mathrm{CH}_{2}\right){ }^{[15]}$ Recyclability of the heterogeneous catalyst. The heterogeneous catalyst was decanted from the reaction mixture by centrifugation and washed twice with $\mathrm{CH}_{2} \mathrm{Cl}_{2}(2 \times 4 \mathrm{~mL})$ prior to use for subsequent reactions.

\section{Acknowledgements}

The support from MINECO/FEDER (projects CONSOLIDER INGENIO-2010 MULTICAT CSD2009-00050 and CTQ201342532-P) and DGA/FSE (group E07) is acknowledged.

Keywords: Copper-NHC • Hydrosilylation $\bullet$ Homogeneous Catalysis • Kinetic studies •

[1] a) B. Marciniec, C. Pietraszuk, I. Kownacki, M. Zaidlewicz, Vinyl- and Aryl Silicon, Germanium, and Boron Compounds, in Comprehensive Organic Functional Group Transformations II, Vol 2, 941 - 1023; (Eds: A. R. Katrizky, J. K. Taylor), Elsevier, Oxford, 2005; b) A. K. Roy, Adv. Organomet. Chem. 2008, 55, 1 - 59; c) B. Marciniec, K. H. Maciejewski, C. Pietraszuk, P. Pawluć, Hydrosilylation: A Comprehensive Review on Recent Advances (Ed: B. Marciniec), Springer, London, 2008; d) P. Pawluć, W. Prukala, B. Marciniec, Eur. J. Org. Chem. 2010, 219 - 229; e) D. Troegel, J. Stohrer, Coord. Chem. Rev. 2011, 255, 1440-1459; f) F. J. Fernández-Alvarez, A. M. Aitani, L. A. Oro, Catal. Sci. Technol. 2014, 4, 611 - 624

[2] a) H. Kaur, F. K. Zinn, E. D. Stevens, S. P. Nolan, Organometallics 2004, 23, 1157 - 1160; b) S. Díez-González, H. Kaur, F. K. Zinn, E. D. Stevens, S. P. Nolan, J. Org. Chem. 2005, 70, 4784 - 4796; c) S. DíezGonzález, S. P. Nolan, Synlett 2007, 2158 - 2167; d) S. Díez-González, E. D. Stevens, N. M. Scott, J. L. Petersen, S. P. Nolan, Chem. Eur. J. 2008, 14, 158 - 168; e) A. Albright, R. E. Gawley, J. Am. Chem. Soc. 2011, 133, 19680 - 19680; f) J. D. Egbert, C. S. J. Cazin, S. P. Nolan, Catal. Sci. Technol. 2013, 3, $912-926 ;$ g) S. R. Roy, S. C. Sau, S. K. Mandal, J. Org. Chem. 2014, 79, 9150 - 9160; h) M. R. Chapman, Y. M. Shafi, N. Kapur, B. N. Nguyen, C. E. Willans, Chem. Commun. 2015, $51,1282-1284$
[3] a) C. Deutsch, N. Krause, B. H. Lipshutz, Chem. Rev. 2008, 108, 2916 - 2927; b) S. Díez-González, S. P. Nolan, Acc. Chem. Res. 2008, 41 349 - 358; c) N. Cox, H. Dang, A. M. Whittaker, G. Lalic, Tetrahedron 2014, 70, 4219 - 4231; d) F. Lazreg, F. Nahra, C. S. J. Cazin, Coord. Chem. Rev. 2015, $293-294,48-79$.

[4] a) N. P. Mankad, D. S. Laitar, J. P. Sadighi, Organometallics 2004, 23, 3369 - 3371; b) L. Zhang, J. Cheng, Z. Hou, Chem. Commun. 2013, 49 , $4782-4784$.

[5] T. Vergote, F. Nahra, A. Merschaert, O. Riant, D. Peeters, T. Leyssens, Organometallics 2014, 33, 1953 - 1963.

[6] a) H. M. J. Wang, I. J. B. Lin, Organometallics 1998, 17, 972 - 975; b) I. J.B. Lin, C. S. Vasam, Coord. Chem. Rev. 2007, 251, 642 - 670; c) F. E. Hahn, M. C. Jahnke, Angew. Chem. Int. Ed. 2008, 47, 3122 - 3172; d) J. C. Y. Lin, R. T. W. Huang, C. S. Lee, A. Bhattacharyya, W. S. Hwang, I. J. B. Lin, Chem. Rev. 2009, 109, 3561 - 3598.

[7] G. Lázaro, F. J. Fernández-Alvarez, M. Iglesias, C. Horna, E. Vispe, R. Sancho, F. J. Lahoz, M. Iglesias, J. J. Pérez-Torrente, L. A. Oro, Catal. Sci. Technol. 2014, 4, $62-70$.

[8] a) G. Venkatachalam, M. Heckenroth, A. Neels, M. Albrecht, Helv. Chim. Acta 2009, 92, 1034 - 1045; b) J. Al Thagfi, S. Dastgir, A. J. Lough, G. G. Lavoie, Organometallics 2010, 29, 3133 - 3138; c) S. Díez-González, E. C. Escudero-Adán, J. Benet-Buchholz, E. D. Stevens, A. M. Z. Slawin, S. P. Nolan, Dalton Trans, 2010, 39, 7595 7606; d) W. Wang, G. Zhang, R. Lang, C. Xia, F. Li, Green Chem. 2013, 15, 635 - 640; e) M. Holtz-Mulholland, S. K. Collins, Synthesis 2014, 46, $375-380$.

[9] a) S. Hohloch C.-Y. Su, B. Sarkar, Eur. J. Inorg. Chem. 2011, 3067 3075; b) A. C. Badaj, G. G. Lavoie, Organometallics 2012, 31, 1103 1111

[10] Cambridge Structural Database (CSD) System. 2015 Release; F.H Allen, Acta Crystallogr. Sect. B 2002, 58, 380 - 388.

[11] M. Jia, A. Seifert, W. R. Thiel, Chem. Mater. 2003, 15, $2174-2180-$

[12] a) C. S. J. Cazin, M. Veith, P. Braunstein, R. B. Bedford, Synthesis 2005, 622 - 626; b) A. Corma, H. Garcia, Adv. Synth. Catal. 2006, 348, 1391 - 1412; c) A. Corma, E. Gutiérrez-Puebla, M. Iglesias, A. Monge S. Pérez-Ferreras, F. Sánchez, Adv. Synth. Catal. 2006, 348, $1899-$ 1907; d) A. Corma, C. González-Arellano, M. Iglesias, S. PérezFerreras, F. Sánchez, Synlett 2007, 1771 - 1774; e) K. H. Park, S. Kim, Y. K. Chung, Bull. Korean Chem. Soc., 2008, 29, 2057 - 2060; f) S. Berardi, M. Carraro, M. Iglesias, A. Sartorel, G. Scorrano, M. Albrecht M. Bonchio, Chem. Eur. J. 2010, 16, 10662 - 10666; g) C. del Pozo, A. Corma, M. Iglesias, F. Sánchez, Organometallics 2010, 29, 4491 4498; h) S. Dastgir, K. S. Coleman, M. L. H. Green, Dalton Trans. 2011, 40, 661 - 672; i) A. Monge-Marcet, R. Pleixats, X. Cattoën, M. Wong Chi Man, Catal. Sci. Technol., 2011, 1, 1544 - 1563; j) M. Baffert, T. K. Maishal, L. Mathey, C. Copéret, C. Thieuleux, ChemSusChem 2011, 4, 1762 - 1765; k) G. Villaverde, A. Corma, M. Iglesias, F Sánchez, ChemCatChem 2011, 3, 1320 - 1328; I) G. Villaverde, A. Corma, M. Iglesias, F. Sánchez, ACS Catal. 2012, 2, 399 - 406; m) K. V. S. Ranganath, S. Onitsuka, A. K. Kumar, J. Inanaga, Catal. Sci. Technol., 2013, 3, 2161 - 2181; n) M. Fernández, M. Ferré, A. PlaQuintana, T. Parella, R. Pleixats, A. Roglans, Eur. J. Org. Chem. 2014 $6242-6251$.

[13] See for some examples: a) P. Li, L. Wang, Y. Zhang, Tetrahedron, 2008, 64, 10825 - 10830; b) M. Wang, P. Li, L. Wang, Eur. J. Org Chem. 2008, 2255 - 2261; c) P. Liu, J. Yang, P. Li, L. Wang, Appl. Organomet. Chem. 2011, 25, 830 - 835; d) L. Wan, C. Cai, Catal. Lett. 2012, 142, 1134 - 1140; e) B. Dervaux, F. E. Du Prez, Chem. Sci. 2012, 3, 959 - 966; f) T. Jin, M. Yan, Y. Yamamoto, ChemCatChem 2012, 4, 1217 - 1229; g) J.-M. Collinson, J. D. E. T. Wilton-Ely, S. DíezGonzález, Chem. Commun. 2013, 49, 11358 - 11360; h) Y. Yang, R. M. Rioux, Green Chem. 2014, 16, 3916 - 3925

[14] a) G. Lázaro, M. Iglesias, F. J. Fernández-Alvarez, P. J. Sanz Miguel, J. J. Pérez-Torrente, L. A. Oro, ChemCatChem 2013, 5, 1133 - 1141; b) G. Lázaro, V. Polo, F. J. Fernández-Alvarez, P. García-Orduña, F. J. 
Lahoz, M. Iglesias, J. J. Pérez-Torrente, L. A. Oro, ChemSusChem 2015, 8, 495 - 503; c) G. Lázaro, F. J. Fernández-Alvarez, J. Munárriz V. Munárriz, V. Polo, M. Iglesias, J. J. Pérez-Torrente, L. A. Oro, Catal. Sci. Technol. 2015, 5, $1878-1887$.

[15] a) V. V. Rostovtsev, L. G. Green, V. V. Fokin, K. B. Sharpless, Angew. Chem. Int. Ed. 2002, 41, 2596 - 2599; b) C. W. Tornøe, C. Christensen M. Meldal, J. Org. Chem. 2002, 67, 3057 - 3064; c) S. Díez-González, A. Correa, L. Cavallo, S. P. Nolan, Chem. Eur. J. 2006, 12, $7558-$ 7564; d) S. Díez-González, E. D. Stevens, S. P. Nolan, Chem. Commun. 2008, 4747 - 4749; e) S. Díez-González, S. P. Nolan, Angew. Chem. Int. Ed. 2008, 47, 8881 - 8884; f) S. Díez-González, E. C. Escudero-Adán, J. Benet-Buchholz, E. D. Stevens, A. M. Z. Slawin, S. P. Nolan, Dalton Trans. 2010, 39, 7595 - 7606.

[16] For some reviews see for example: a) M. Medal, C. W. Tornøe, Chem. Rev. 2008, 108, 2952 - 3015; b) J. E. Hein, V. V. Fokin, Chem. Soc. Rev. 2010, 39, 1302 - 1315; c) Y. Xing, N.-X. Wang, Coord. Chem. Rev. 2012, 256, 938 - 952; d) B. Schulze, U. S. Schubert, Chem. Soc. Rev. 2014, 43, 2522 - 2571; e) L. Liang, D. Astruc, Coord. Chem. Rev. 2011, 255, 2933 - 2945.

[17] P. Appukkuttan, W. Dehaen, V. V. Fokin, E. van der Eycken, Org. Lett. 2004, 6, $4223-4225$.

[18] H. Q. Liu, J. F. Harrod, Can. J. Chem. 1990, 68, $1100-1105$
[19] a) G. Zhang, X. Wang, J. Long, L. Xie, Z. Ding, L. Wu, Z. Li, X. Fu, Chem. Mater. 2008, 20, 4565 - 4575; b) G. Zhang, J. Long, X. Wang W. Dai, Z. Li, L. Wu, X. Fu, New J. Chem. 2009, 33, 2044 - 2050; c) K. L. Fujdala, I. J. Drake, A. T. Bell, T. D. Tilley, J. Am. Chem. Soc. 2004, 126, $10864-10866$.

[20] SAINT+, Version 6.01: Area-Detector Integration Software, Bruker AXS Madison WI, 2001.

[21] SADABS, Area-Detector Absorption Correction Program, Bruker AXS Madison WI, 1996

[22] G. M. Sheldrick, Acta Crystallogr. Sect. A 1990, 46, $467-473$

[23] a) G. M. Sheldrick, Methods Enzymol. 1997, 276, 628 - 641; b) G. M. Sheldrick, Acta Crystallogr. Sect. A. 2008, 64, $112-122$.

[24] G. M. Sheldrick, Acta Crystallogr. Sect. C. 2015, 71, 3-8. 
